\title{
Clitoromegaly: beyond testosterone
}

\section{Darshana Sudip Thakur, ${ }^{1}$ Chaitanya G Yerawar, ${ }^{1}$ Meghana Phiske, ${ }^{2}$ Nikhil M Bhagwat ${ }^{1}$}

'Department of Endocrinology, Topiwala National Medical College and BYL Nair Charitable Hospital, Mumbai, Maharashtra, India

2Department of Dermatology, Topiwala National Medical College and BYL Nair Charitable Hospital, Mumbai, Maharashtra, India

\section{Correspondence to} Dr Nikhil M Bhagwat, bhagwatnik@yahoo.co.in

Accepted 6 June 2018

\section{DESCRIPTION}

A 9-year-old girl was presented for evaluation of clitoromegaly (figure 1). There was no evidence of adrenarche, thelarche or accelerated growth. The parents denied a history suggestive of adrenal crisis or progressive hyperpigmentation. On examination, there was clitoral enlargement $(3 \times 1 \mathrm{~cm})$, a plexiform neuroma involving right labia majora (figure 1) and surrounding area of right buttock and thigh (figures 1 and 2) and multiple café au lait spots over the body, freckling over her palms (Patrick Yesudian sign) and axilla (Crowe sign) and a sacral dimple with overlying tuft of hair (figure 2). Investigations revealed 46XX karyotype as well as prepubertal luteinizing hormone $(0.2 \mathrm{mIU} / \mathrm{mL})$, follicle-stimulating hormone $(1.5 \mathrm{mIU} / \mathrm{mL})$ and testosterone $(0.3 \mathrm{ng} / \mathrm{mL})$ levels. The 17 hydroxyprogesterone levels $(<0.1 \mathrm{ng} / \mathrm{mL})$, cortisol $(18.4 \mu \mathrm{g} / \mathrm{dL})$ and thyroid function tests $(\mathrm{T} 3=154.6 \mathrm{ng} / \mathrm{dL}, 10.2 \mu \mathrm{g} /$ $\mathrm{dL}$, thyroid stimulating hormone $=5.3 \mu \mathrm{IU} / \mathrm{mL}$ ) were normal. The diagnosis of neurofibromatosis (NF) was initially made clinically based on the presence of café au lait spots, plexiform neuroma and axillary freckling. Abdominal and pelvic MRI revealed diffuse thickening of the skin and subcutaneous tissue with altered intensity of right posterior gluteal region with involvement of bilateral labial fold and extension into left gluteal fold and dural ectasia with scalloping of vertebrae further supporting the diagnosis of NF. The adrenal glands were normal and there was no evidence of any other mass lesion (figure 3). Biopsy performed from the right perineal region showed a basket wave stratum corneum, increased basal cell layer melanisation with dermis showing loose delicate wavy collagen with non-encapsulated loose textured tumour extending up to subcutaneous tissue and composed of delicate single fascicle with spindle-shaped nuclei (figure 4), confirming

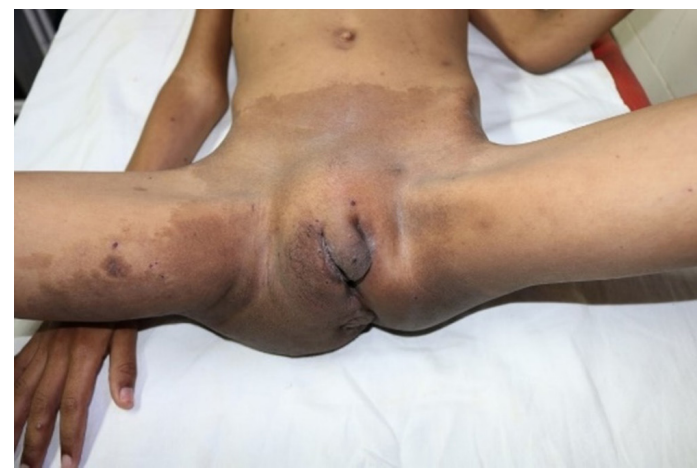

Figure 1 Clitoral enlargement, café au lait macule and plexiform neuroma involving right buttock.

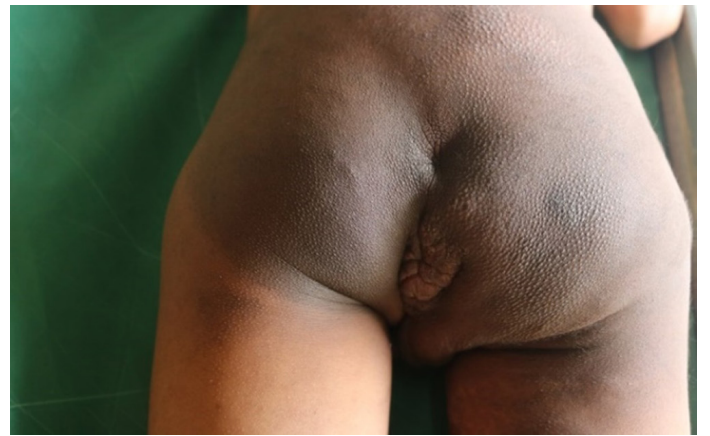

Figure 2 Plexiform neuroma, café au lait macule and sacral dimple.

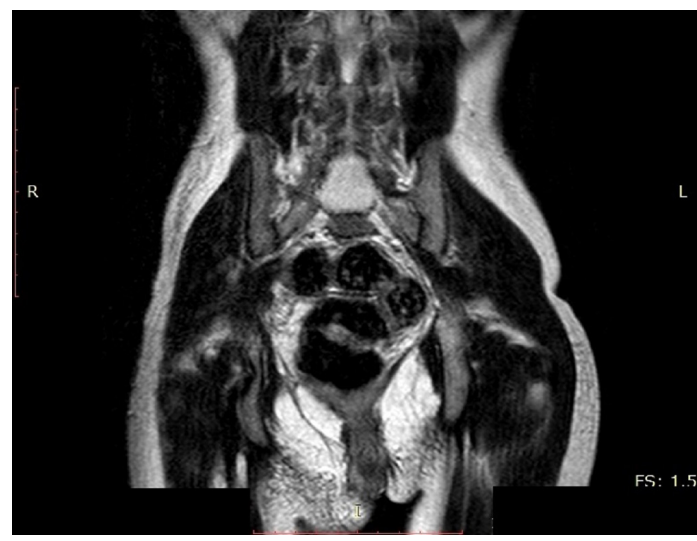

Figure 3 MRI of the abdomen and pelvis showing thickening of skin and subcutaneous tissue of perineal and gluteal region.

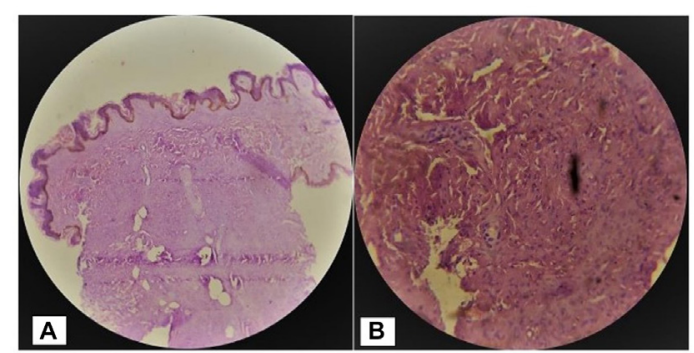

Figure 4 Histopathology from the right perineal region $(A)$ low power and $(B)$ high power.

the diagnosis of plexiform neuroma. This is a rare case of pseudoclitoromegaly due to NF involving the genital region. Clitoral enlargement could rarely be the sole presenting feature of genital NF.

Copcu et al divided the causes of clitoromegaly into hormonal and non-hormonal conditions, pseudoclitoromegaly and idiopathic clitoromegaly. ${ }^{1}$ Clitoral enlargement in NF is an androgen-independent process and the pathogenesis 
is similar to the formation of neurofibromas. It occurs from the second hit (somatic mutation or loss of heterozygosity) in those who carry a germ line mutation, which leads to complete loss of neurofibromin expression. This results in abnormal division of Schwann cells and their interaction with perineural cells, mast cells, fibroblasts and neurons manifesting as neurofibromas. ${ }^{2}$ A similar case of NF with clitoromegaly described by Karabouta et al stressed on the importance of follow-up to detect other manifestations and complications of this syndrome for timely interventions. ${ }^{3}$

\section{Learning points}

- Clitoral enlargement can be the presenting feature of genital neurofibromatosis.

- Meticulous clinical examination may prevent unnecessary investigations and treatment for clitoromegaly.
Contributors DST and CGY has conceptualised and designed the case report. DST and MP has contributed to acquisition and interpretation of data. DST, CGY and NMB drafted the article. NMB finalised the article by revising and editing it critically.

Funding The authors have not declared a specific grant for this research from any funding agency in the public, commercial or not-for-profit sectors.

Competing interests None declared.

Patient consent Parental/guardian consent obtained.

Provenance and peer review Not commissioned; externally peer reviewed.

(c) BMJ Publishing Group Ltd (unless otherwise stated in the text of the article) 2018. All rights reserved. No commercial use is permitted unless otherwise expressly granted.

\section{REFERENCES}

1 Copcu E, Aktas A, Sivrioglu N, et al. Idiopathic isolated clitoromegaly: a report of two cases. Reprod Health 2004;1:4.

2 Maertens O, Brems H, Vandesompele J, et al. Comprehensive NF1 screening on cultured Schwann cells from neurofibromas. Hum Mutat 2006:27:1030-40.

3 Karabouta Z, Rousso I, Athanassiadou-Piperopoulou F. Clitoromegaly as first presentation of a neurocutaneous syndrome in a 3-year-old girl. Clin Case Rep 2015:3:767-8.

Copyright 2018 BMJ Publishing Group. All rights reserved. For permission to reuse any of this content visit

http://group.bmj.com/group/rights-licensing/permissions.

BMJ Case Report Fellows may re-use this article for personal use and teaching without any further permission.

Become a Fellow of BMJ Case Reports today and you can:

- Submit as many cases as you like

- Enjoy fast sympathetic peer review and rapid publication of accepted articles

- Access all the published articles

Re-use any of the published material for personal use and teaching without further permission

For information on Institutional Fellowships contact consortiasales@bmjgroup.com

Visit casereports.bmj.com for more articles like this and to become a Fellow 